\title{
Einfühlung e Campo Semântico: uma Investigação Fenomenológica de suas Diferenças e Aproximações
}

\author{
Wilian Mauri Friedrich Neu ${ }^{1}$ \\ Mateus Renard Machado ${ }^{2}$
}

\begin{abstract}
Resumo: O presente estudo concentra-se na investigação dos conceitos de campo semântico e da Einfühlung, que são significativamente importantes à compreensão da ciência moderna e, sobretudo, ao entendimento do ser humano. Neste sentido, a análise posta em relevo teve por objetivo principal verificar a relação existente, ou não, entre a Einfühlung, de Edmund Husserl, e o campo semântico, de Antonio Meneghetti, em uma análise dialética de ambas as teorias. Ao final do percurso investigativo, pôde-se concluir que os conceitos teoréticos da Einfühlung e do campo semântico se constituem de forma similar, especialmente, pelo entendimento comum de que ambos caracterizam um mecanismo natural-inteligente, que é capaz de compreensão pré-atencional/consciente sobre os atos da vivência humana.
\end{abstract}

Palavras-chave: Einfühlung; Campo Semântico; Diferenças e Aproximações.

Einfühlung and the Semantic Field: a phenomenological investigation of their differences and approaches.

Abstract: This study focuses on the investigation of the concepts of semantic field and Einfühlung, which are significantly important to the understanding of modern science and, above all, to the understanding of the human being. In this sense, the main focus of the analysis was to verify the relationship, whether or not, between Edmund Husserl's Einfühlung and Antonio Meneghetti's semantic field, in a dialectical analysis of both theories. At the end of the investigative path, it could be concluded that the theoretical concepts of Einfühlung and the Semantic Field are constituted in a similar way, especially by the common understanding that both characterize a natural-intelligent mechanism, which is capable of pre-attentional understanding/conscious about the acts of human experience.

Keywords: Einfühlung; Semantic Field; Differences and Approximations.

Einfühlung y el campo semántico: una investigación fenomenológica de sus diferencias y enfoques.

Resumen: Este estudio se centra en la investigación de los conceptos de campo semántico y Einfühlung, que son significativamente importantes para la comprensión de la ciencia

\footnotetext{
${ }^{1}$ Bacharel em Direito pela Faculdade Antonio Meneghetti (AMF); Especialista em Direito Tributário pela Pontifícia Universidade Católica de Minas Gerais (PUC-MG); Especialista em Ensino de Filosofia pela Universidade Federal de Pelotas (UFPEL); Consultor de Compliance Fiscal pelo Grupo Studio; participou do Grupo de Pesquisa e Extensão Fundamentos do Novo Código de Processo Civil pela AMF, sob coordenação do Prof. Pós-Doutor Cristiano Isaia Becker (2018 - 2019; participante do Grupo de Pesquisa e Extensão em Ética e Teoria da Justiça - GEETJ; participante do Grupo de Pesquisa e Extensão Hard Cases; participante do Grupo de Pesquisa em Direito Empresarial e Tributário junto à OAB/RS, subseção de Santa Maria/RS; participante de curso de língua alemã pelo Instituto Cultural Brasileiro-Alemão (ICBA) de Santa Maria/RS; e membro fundador do Projeto Ambiental Plantando Vida (2017); Advogado OAB/RS 119.502. E-mail: rs.wilianfriedrich@grupostudio.com.br.

${ }^{2}$ Licenciado em Filosofia pela Universidade Federal de Santa Maria (UFSM); Bacharel em Direito (UFSM); Especializando em Ontopsicologia pela Faculdade Antonio Meneghetti (AMF); Mestre em Filosofia (UFSM); Tem experiência nas áreas de Filosofia, Sociologia e Direito. No campo filosófico: Ética, Filosofia Política e Filosofia do Direito. Na área jurídica: Teoria do Direito e Direito das Coisas. Na Sociologia: Teoria dos Sistemas e Sociologia do Direito. E-mail: mateus_machado@hotmail.com.
} 
moderna y, sobre todo, para la comprensión del ser humano. En este sentido, el enfoque principal del análisis fue verificar la relación, sea o no, entre Einfühlung de Edmund Husserl y el campo semántico de Antonio Meneghetti, en un análisis dialéctico de ambas teorías. Al final del camino de investigación, se podría concluir que los conceptos teóricos de Einfühlung y el Campo Semántico están constituidos de manera similar, especialmente por la comprensión común que ambos caracterizan un mecanismo inteligente natural, que es capaz de comprender previamente la atención/consciente de los actos de la experiencia humana.

Palabras clave: Einfühlung; Campo semantico; Diferencias y aproximaciones.

\section{Introdução}

A fenomenologia, especialmente, no início do século XX, configurou-se como uma das principais correntes de estudo não só da Filosofia, mas de diversas áreas do conhecimento, como a própria psicologia e também o Direito. A descoberta do campo semântico, por sua vez, também é fruto de um desenvolvimento científico e filosófico que pode ser interpretada, aqui, como uma evolução do conceito formulado por Husserl, ainda que não se tenha nenhuma indicação expressa desta ligação.

No início do século passado, Edmund Husserl funda a fenomenologia que, para além de uma escola filosófica, tinha como propósito estabelecer um método próprio e de rigor, capaz de fundamentar as demais ciências. Neste percurso filosófico, o pensador alemão descobre um ato anterior aos atos da consciência, denominado por ele pela expressão alemã Einfühlung, ou, em traduções mais vulgares para o português, "entropatia", "empatia" ou, ainda, "intropatia". 3

A questão central envolvendo a descoberta husserliana é a busca por responder algumas indagações, como, por exemplo, será que o mundo não é uma mera projeção do eu? Como podemos perceber o wir $^{4}$ ? E, por fim, o que são e como surgem os atos tidos como conscientes?

E, para que as indagações fossem devidamente respondidas, Husserl mergulha no campo dos atos da consciência, percebendo que o ser humano pode, sempre e imediatamente, perceber e distinguir o homem dos animais, vegetais e das demais coisas, sem que seja necessário refletir sobre (ato espiritual). Aliás, a Einfühlung configura um ato involuntário

\footnotetext{
${ }^{3}$ Como é comum, algumas palavras do alemão não encontram uma exata correspondência na língua portuguesa. Neste trabalho, para evitar equivocadas interpretações em relação à tradução, manter-se-á a expressão original do alemão.

${ }^{4}$ Expressão alemã que designa "nós", na tradução para o português.
} 
e prévio aos atos espirituais que, não de forma isolada, dá-se a partir da conjugação com outros atos, como aqueles corpóreos.

O campo semântico, por outro lado, enquanto descoberta de Meneghetti, configurase num aparelho, teoricamente mais desenvolvido pelo humano, capaz de transdução de informação, sem a transferência de energia, de uma pessoa a outra. Especifica-se, portanto, a vetorialidade de ação de um em si por aquela pessoa capaz de ler o campo semântico.

Diante disso, a pergunta que merece uma reflexão e que instiga a presente pesquisa é: há uma relação entre a Einfühlung e o campo semântico? E, havendo, quais as suas diferenças e similaridades? Para responder a esta problemática, utilizar-se-á o método de pesquisa dialético, confrontando-se a teoria husserliana à descoberta proposta por Meneghetti.

O objetivo central da presente investigação é verificar a relação existente, ou não, entre a Einfühlung, formulada pelos fenomenólogos Edmund Husserl e Edith Stein, com a descoberta do campo semântico, proposta por Antonio Meneghetti. Especificadamente, o trabalho será dividido em três grandes seções, as quais terão por objetivo específico, primeiro: verificar o que é Einfühlung; segundo, investigar o que é campo semântico; e terceiro, analisar a relação entre Einfühlung e campo semântico e as suas respectivas consequências.

Portanto, verifica-se que a problemática posta em relevo, por si só, já justifica a presente investigação. A análise dos atos da consciência, especificadamente, a Einfühlung, e também a verificação do campo semântico e a correlação entre ambos significam muito mais do que uma simples investigação científica, pois permitem uma analítica que consequentemente reflete na própria compreensão do ser humano, que, em última instância, é o grande objetivo deste percurso investigativo, ainda que genericamente.

\section{Fundamentação Teórica}

\subsection{Os Atos da Consciência e a Einfühlung como Revelação A Priori}

A investigação posta em pauta revela, primeiramente, duas grandes dificuldades. A primeira delas, é a de que Edmund Husserl nunca chegou a publicar uma obra que refletisse a totalidade de seu pensamento, encontrando-se seus escritos de forma fragmentada (2006, p. 13). A segunda, e talvez a mais difícil, é a de que inexiste qualquer estudo que até hoje 
tenha correlacionado a teoria da Einfühlung, formulada pelo filósofo alemão, com a descoberta do campo semântico, proposta por Antonio Meneghetti.

Antes de propriamente adentrar-se no campo da Einfühlung, enquanto teoria, ter-seá de apresentar, ainda que resumidamente, algumas ideias centrais do pensamento husserliano, que servirão de base para que seja possível uma adequada compreensão da sua filosofia. Um ponto importante é refletir o surgimento da ciência moderna, que, em sua base elementar, parte da razão metodologicamente estruturada para reverenciar uma maior rigorosidade no pensamento, o que, por consequência, ordenou o pensar em uma dualidade, que separa o sujeito e o objeto. ${ }^{5}$

A ciência passou a objetificar o mundo cognoscível. Carotenuto explica que "o positivismo materialista do século XIX absolutizou o valor do objetivismo científico" (2009, p. 238). Eis, neste momento, a renúncia da problemática do sentido. A partir da problemática anunciada, Husserl propõe uma nova forma de se conhecer, isto é, uma nova "teoria do conhecimento", que seja capaz de unificar sujeito e objeto, servindo como base elementar para qualquer ciência e, sobretudo, para uma filosofia de rigor.

A fenomenologia, enquanto movimento filosófico, despertou propriamente com Husserl no final do século XIX, ganhando força no início do século seguinte. E, para iniciar este percurso, não há outro caminho senão o de apresentar resumidamente o que é fenômeno e fenomenologia, na visão husserliana:

Fenômeno é aquilo que se mostra; não somente aquilo que aparece ou parece, e "Logia" que deriva da palavra logos, que para os gregos tinha muitos significados, tais como: palavra, pensamento. Vamos tomar logos como pensamento, como capacidade de refletir. Tomemos, então, fenomenologia como reflexão sobre um fenômeno ou sobre aquilo que se mostra. A Fenomenologia começou como uma escola filosófica cujo pai e mestre é E. Husserl. O seu início sistemático se deu na Alemanha, em fins do século XIX, e na primeira metade do século XX (2006, p. 17-18).

A partir desta síntese, corre-se o risco de equivocadas intepretações acerca do que é fenômeno. A definição acima explicitada traz fenômeno no sentido de "o que se mostra" e não o que parece ou propriamente aparece. Aqui reside um grande perigo, pois pode-se

\footnotetext{
${ }^{5}$ Isso significaria que o objeto do conhecimento em relação ao sujeito é independente, autônomo, isto é, o sujeito não o influi cognitivamente. O conhecer estrutura-se, nesta linha, por uma forma analítica-quantitativa em relação ao objeto investigado. Sobre este ponto, ver: CAROTENUTO, M. Histórico sobre as teorias do conhecimento. Tradução: Ontopsicologica Editrice. Recanto Maestro: Ontopsicologica Editrice, 2009.
} 
confundir a fenomenologia com a ideia formulada no realismo platônico, isto é, na metodologia da reminiscência.

Fenomenologia apresenta-se, na perspectiva husserliana, como um método capaz de fundamentar todas as demais ciências. Nesta linha, a fenomenologia, em suas origens, surgiu de uma reação "antimetafísica", como proposta pelo seu fundador, "um retorno às coisas próprias elas mesmas" (1996, p. 9). Isso significa, de modo geral, abdicar do ponto de vista de Deus, isto é, em termos práticos, de uma tentativa de dar resposta à pergunta exposta por Leibniz, "pourquoi y a-t-il quelque chose plutôt que rien?"6 (SANTOS, 2007, p. 45). Neste mesmo sentido, o autor explicita:

\begin{abstract}
Negativamente, o "retorno" fenomenológico marca a renúncia a uma imaginação especulativa que ainda caracterizava o idealismo alemão pós-kantiano. Positivamente, ele significa não apenas uma reabilitação da "certeza sensível", tão menosprezada por Hegel e que se torna, para Husserl, "intuição doadora de sentido", mas, sobretudo, uma análise da génese do sentido ao nível mais elementar da experiência sensível, do phainestai (do aparecer) do sensível. O conceito fenomenológico de fenómeno não remete para uma "aparência" ocultadora de uma inacessível "coisa em si"; nada se esconde por trás da aparição. E de nada adianta ver no sensível a "expressão" do "absoluto" (SANTOS, 2007, p. 45).
\end{abstract}

Para que isso seja possível, busca nos atos da consciência uma forma não só de explicar os fenômenos, mas, sobretudo, de explicitar o ser humano em sua estrutura universal. A compreensão sobre a fenomenologia, para Husserl, na visão da pensadora italiana Ales Bello, é a de que:

\begin{abstract}
As coisas se mostram a nós. Nós é que buscamos o significado, o sentido daquilo que se mostra. [...] Todas as coisas que se mostram a nós, pois tratamos como fenômenos, porque conseguimos compreender o sentido. Entretanto o fato de se mostrarem não nos interessa tanto, mas, sim, compreender o que são, isto é, o seu sentido (2006, p. 19).
\end{abstract}

Aliás, este "retorno às coisas elas mesmas" retoma outra grande preocupação de Husserl (1996, p. 12), que, na essência de seu pensamento, buscou tornar a filosofia "uma ciência rígida", fundada em um método. Isso está expresso no início de uma de suas principais obras, Investigações Lógicas - Sexta Investigação, donde se extrai a seguinte proposição:

\footnotetext{
6 “Por que existe algo em vez de nada?" Ver em: SANTOS, J. M. Os Argonautas da Razão. Da Fenomenologia à Teoria dos Sistemas. Phainomenon, [S.1.], n. 14, p. 45-60, oct. 2007. ISSN 2183-0142.
} 
A primeira consiste no fato de Descartes ter imposto à filosofia algo que para Husserl é a pedra do filosofar, isto é, ter imposto a necessidade de um método que obrigue a uma reflexão radical sobre os procedimentos adequados para o pensamento filosófico; a segunda, consiste no fato de Descartes ter encontrado o Cogito como primeira verdade indubitável para começar a pensar corretamente. $\mathrm{O}$ Cogito, isto é, a subjetividade (1996, p. 12).

E, portanto, aqui está devidamente anunciado o ponto central da fenomenologia: o que interessa, em verdade, no fenômeno, é o seu sentido. O sentido das coisas elas mesmas é, deste modo, o próprio objetivo da fenomenologia e da filosofia husserliana, como um todo. Esta mesma interpretação é dada por Ales Bello:

\begin{abstract}
O nosso problema é: o que é que se mostra e como se mostra. Quando dizemos que alguma coisa se mostra, dizemos que ela se mostra a nós, ao ser humano, à pessoa humana. Isso tem grande importância. Em toda a história da filosofia sempre se deu muita importância ao ser humano, àquele a quem o fenômeno se mostra. As coisas se mostram a nós. Nós é que buscamos o significado, o sentido daquilo que se mostra. Num primeiro momento, podemos pensar que aquilo que se mostra esteja ligado ao mundo físico diante de nós, mais do que dizer "as coisas se mostram", precisamos dizer que "percebemos, estamos voltados para elas", principalmente para aquilo que aparece no mundo físico $(2006$, p. 19).
\end{abstract}

Assim, a filosofia inaugurada por Husserl pressupõe que o ser humano possui a capacidade de intuir o sentido das coisas, captando sua essência pelo seu sentido. Dá-se um exemplo: um determinado indivíduo, ao chegar em uma residência, aperta a campainha. Todos que estão dentro desta casa, imediatamente e intuitivamente captam que alguém chegou e está ali, esperando para ser atendido (captam inclusive e de forma pré-consciente tratar-se de um ser humano). Se, ao contrário, alguém não identifica este som, significa que possivelmente possui algum problema relacionado ao sentido auditivo.

Percebam, com este exemplo, que para Husserl não é tão significante o fato em si, mas sim o seu sentido, que, no caso, serio o de "chamar alguém a lhe atender", "avisar-lhe que chegou". Desta maneira, a própria existência fática é colocada entre "parênteses" para se verificar o seu sentido de ser, isto é, sua essência. ${ }^{7}$

Isto significa, em outras palavras, que o Eu Transcendental suspende tudo aquilo que os "eus" carregam enquanto vivências, isto é, caracteriza-se por uma suspensão às crenças,

\footnotetext{
${ }^{7}$ Sobre este aspecto de sua filosofia que reside a grande divergência husserliana com os denominados positivistas. Como acima explicitado, para Husserl os fatos existem mas não são o mais significante, pois o importante é captar o seu sentido. Os positivistas, ao contrário, compreendem os fatos como o mais relevante, tentando decifrá-los qualitativa ou quantitativamente, não observando o seu sentido em si.
} 
às tradições, às ciências, ao próprio “eu”. É, sobretudo, uma forma de se ponderar a validade do mundo e partir de uma nova concepção, de uma consciência pura.

E neste contexto, Alécio Vidor explica que para o pensador alemão (2013, p. 27), para que qualquer conhecimento seja válido, faz-se necessário que o pesquisador seja autêntico. Afirma o autor que "pela epoché eu suspendo até os valores de ser incluídos nos modos de consciência, e deste modo o Ego se faz distinto numa evidência a priori, enquanto ser próprio deste Ego" (2013, p. 27). Esta consciência historicamente caminha em duas direções: a do objetivismo fisicalista (ciências da natureza) e a do subjetivismo transcendental (ciências do espírito). Husserl considera ser fundamentalmente necessário uma unificação destas duas áreas, caso contrário, uma irá agir sobre a outra (2013, p. 13).

A partir da análise dos atos da consciência é que Husserl verifica que a composição do homem, enquanto teoria da compreensão, não é exatamente aquela formulada por Aristóteles. O pensador grego, na obra Peri Psykhês (De Anima), conjectura a Psykhês (alma) como princípio animador de todos os seres vivos. ${ }^{8}$ Portanto, a alma difere os seres animados dos inanimados. ${ }^{9}$

Para Aristóteles, ${ }^{10}$ um dos gêneros do ser é a substância, que, num primeiro sentido, é a matéria (que em si não é um isto, ou seja, um ser, mas faz parte) e, em um segundo momento, substância é forma da qual o isto é chamado, e num terceiro sentido, é um composto de ambas. A matéria é potência, ao passo que a forma é ato, realização (2011, p. $71)$.

Conforme dito acima, Husserl, a partir da análise dos atos da consciência, concebe o ser humano como sendo composto por três dimensões e não duas, como para Aristóteles, sendo elas: corpo, psique e espírito. E a partir de um simples exemplo, compreende-se como Husserl chega a tais conclusões. Imagine-se que você em um dia muito quente esteja caminhando por determinado período de tempo e, já cansado, avista uma praça que possui

\footnotetext{
${ }^{8}$ De Anima (DA) 402a1: "a alma é como o princípio dos animais".

${ }^{9}$ Se, matéria é potência e alma é realização (ato), e se substância é comumente entendida como: matéria, forma e o composto de ambas. E se o composto de ambas é o que anima o ser, sendo que se assim não o fosse, este seria inanimado, pode-se concluir que não é o corpo o ato da alma, mas sim a alma que é o ato do corpo, pois, anima-o. Alma não é um corpo, mas é relativo a ele.

${ }^{10}$ Resumidamente, a alma e o corpo não são a mesma coisa, ainda que sejam correlatas e estejam em uma mesma dimensão. Alma é forma e o corpo é a matéria, corpo é potência e a alma é a sua atualidade. Alma é uma substância no sentido de noção, compreendida como essência própria deste ou daquele corpo (412b10). Uma atualidade poderá ser se, antes, há uma potência que a permita ser, o corpo, enquanto potencialidade. A constituição do homem é, por óbvio, dualista, corpo e alma.
} 
um chafariz jorrando uma água límpida. Imediata e intuitivamente, você vê a água. $\mathrm{O}$ ato de ver é um ato sensível (da percepção/sensação), classificado por Husserl como ato corpóreo.

Ao ver, instintivamente sente sede, que seria classificado como um segundo ato, de ordem psíquica, pois involuntário (sentir sede, forme, frio, calor, entre outras fenomenologias, independem da vontade humana). E, por fim, ao sentir sede, o indivíduo é capaz de realizar outro ato, completamente diferente do ver (ato corpóreo) e do sentir sede (ato psíquico), que seria o de refletir, denominado como ato espiritual. ${ }^{11}$

Assim, em uma perspectiva husserliana, é possível lidar com os infinitos potenciais das múltiplas faces dos objetos. Para Husserl, este potencial ora anunciado deveria ocupar o ilusório lugar do infinito atual estabelecido pela metafísica, uma vez que o infinito dos perfis ou faces da percepção não exclui evidências, certezas, intuições doadoras, sentidos (2007, p. 47). Toda esta introdução é necessária para uma adequada compreensão do terreno fenomenológico e, sobretudo, do conceito da Einfühlung.

E, antes de explicá-la, traz-se propriamente a origem etimológica do conceito "Einfühlung". Em sua etimologia, é formada pelas palavras "Ein" (um/em), fühlen (sentir) e ung (sentindo - colocando a expressão no gerúndio), o que vai de encontro à tradução exprimida por Ales Bello (2004). ${ }^{12}$ Mas, de pronto pode-se acreditar precipitadamente tratarse de conceito idêntico ao de empatia, que traz na sua origem grega pathos o "sentir junto/em". Inclusive, alguns autores apresentam ao conceito de Einfühlung uma interpretação, no mínimo, perigosa, como, a exemplo, a dada por Manganaro (2002), que entende como "sentir dentro" ou "sentir dentro do outro".

No entanto, Einfühlung está em um nível anterior à empatia, uma vez que esta é muitas vezes utilizada também no sentido de simpatia, sendo um ato específico psíquico reativo a uma determinada pessoa. Por exemplo, ao conversar com alguém, imediatamente e reativamente ativo o ato psíquico da simpatia ou antipatia e, além disso, o sofrer deste indivíduo (no sentido "do que lhe atinge", "do que se passa”) pode ou não impactar em mim. Mas, o que me faz perceber, imediatamente, que este alguém a quem eu me dirijo é um ser

\footnotetext{
11 Ao explicitar desta forma, Husserl vai além da compreensão elaborada por Aristóteles e também, posteriormente, por Jung, que ainda que reconheça a existência dos atos psíquicos e espirituais, não faz a sua distinção. Inclusive, para Bello (2006, p. 53), “é como se Jung atribuísse à psique aquilo que é psíquica e espiritual ao mesmo tempo, não distinguisse os dois níveis, não reconhecesse a autonomia do nível espiritual". 12 Ver em: BELLO, A. A. Introdução à Fenomenologia. Tradução: Ir. Jacinta T. Garcia e Miguel Mahfoud. Bauru/SP: Edusc, 2006. Embora Ales Bello não tenha interpelado a terceira parte da palavra Einfühlung "ung”, não parece haver uma diferença no seu sentido, sendo, portanto, uma interpretação bastante precisa do conceito.
} 
humano, é um $e u$ e, por ser um $e u$, possibilita o wir? É justamente esta capacidade anterior que, involuntariamente, capta a presença de outro ser humano, outro animal, outro objeto.

Para esclarecer a Einfühlung, talvez seja interessante explicitar-se sobre a fase anterior à consciência. Ao analisar-se os atos, temo-nos como cônscios, ainda que, em um nível espiritual, não tenhamos feito uma análise sobre eles. Não obstante, Husserl havia percebido que existia um nível elementar anterior (nível pré-consciente), do qual denominou como síntese passiva. Ales Bello compreende que a síntese passiva dá-se quando "nós reunimos elementos sem nos darmos conta de que o estamos fazendo" (2006, p. 55). Explicase:

\begin{abstract}
Podemos dizer, por exemplo, que tínhamos a percepção do copo, mas para isso tivemos de exercitar algumas operações anteriormente (a distinção entre um objeto e outro, entre o copo e a toalha...). Trata-se de operações que estabelecem continuidade e descontinuidade, homogeneidade e heterogeneidade (...). Não nos damos conta de operar tudo isso precedentemente à percepção, pois são operações que cumprimos num nível passivo, somos afetados por elas antes que façamos qualquer coisa (2006, p. 55-56).
\end{abstract}

E a provocação que faz Husserl intuir a Einfühlung é a busca pela origem do conhecimento sobre estes atos da consciência. O como e o porquê conseguimos distinguir as coisas, os seres humanos dos demais animais, dos demais objetos. Mas, neste caminhar, o filósofo alemão percebeu que os atos da consciência, aqui entendidos como gênero, não são tão somente compreendidos pelos atos perceptivos, que são espécies os atos corpóreos ou da sensação, os psíquicos e os espirituais. Há, ainda, as operações da síntese passiva e a Einfühlung, dentre as espécies de atos da consciência. ${ }^{13}$

Ales Bello resume a Einfühlung do seguinte modo: "o Einfühlung, entropatia, quer dizer que sinto a existência de um outro ser humano, como eu, é, portanto, uma apreensão de semelhança imediata" (2006, p. 61). Esta apreensão por semelhança não diz respeito somente ao ser humano, mas, também, aos demais animais, seres vivos, e objetos.

A Einfühlung permite um acesso anterior imediato e involuntário à interioridade do fenômeno alter ego, isto é, permite a identificação instantânea não só do wir, mas sua distinção; esta ocorre possivelmente por operar-se em simultaneidade com a síntese passiva, por processos de continuidade e descontinuidade, homogeneidade e heterogeneidade.

\footnotetext{
${ }^{13}$ Posteriormente, com Edith Stein, pode-se chegar à conclusão de que síntese passiva e Einfühlung também significam a mesma coisa, talvez em níveis diferentes.
} 
Por fim, importante explicitar que, na fenomenologia, a Einfühlung permite não só entender a própria corporeidade em si, mas, sobretudo, o modo como reagimos às circunstâncias do mundo-da-vida, como o compreendemos, tendo como ponto de partida as vivências intersubjetivas. Para Husserl, "o mundo intersubjetivo é o correlato da experiência intersubjetiva, isto é, da experiência mediada por “empatia"”14 (2006, § 151, p. 335).

Portanto, Einfühlung consiste propriamente em um mecanismo natural-inteligente capaz de automática compreensão pré-atencional/consciente sobre os atos vivenciais, que, em um segundo nível, pode ser compreendido em nível consciente e reflexivo, em correlação aos demais atos perceptivos.

\subsection{A Fenomenologia do Campo Semântico}

Neste segundo capítulo, buscar-se-á explicitar a estruturação dada ao campo semântico por Meneghetti, suas características principais e sua aplicabilidade, sem, obviamente, esgotar o assunto.

No pensamento do autor italiano (2012, p. 38), campo semântico pode ser traduzido como "uma comunicação base que a vida usa no interior das próprias individuações". É a sua primeira descoberta e que serve como base elementar ao conhecimento do Em Si ôntico ${ }^{15}$ individualizado.

O pensador italiano conjectura na existência humana uma inteligência de natureza, de nascença, que tenciona, isto é, que possui uma ordem de vida. É uma ordem apriórica da própria vida, constituinte do ser humano e que, se desenvolvida, possibilita a realização do homem transcendente em seu tempo.

Se há, nesta perspectiva, uma ordem de natureza, por óbvio, teria de haver, igualmente, uma que não segue aquela naturística. Meneghetti então propõe uma consciência que segue padrões convencionais, estruturados por um critério convencional, como a família, o Estado, a sociedade (entendida no sentido lato sensu), e um critério natural, que emana da própria vida.

E qual é, por assim dizer, a relação entre campo semântico e Em Si ôntico? É, em uma linguagem vulgar, uma ferramenta humana (campo semântico) capaz de ler e individuar

\footnotetext{
${ }^{14}$ Como alertado acima, nesta tradução para o português, "Einfühlung" aparece traduzida como "empatia".

${ }^{15}$ De acordo com o Dicionário de Ontopsicologia, Em Si ôntico é o "projeto-base de natureza que constitui o ser humano" (2012a, p. 84).
} 
não só o projeto de natureza, mas, também, as fenomenologias conscientes e inconscientes circundantes da própria existência.

Significa dizer, portanto, que o universo acontece permeado de relações e, nestas, estamos continuamente inseridos, comunicando e sendo comunicados. Esta interação é energética, na medida em que há sempre um emissor e um receptor. Não há, de todo modo, transdução de energia, o que há, em verdade, é uma informação ${ }^{16}$ que gera alteração energética no receptor. Assim Meneghetti explica que "é um transdutor informático sem deslocamento de energia” (2010, p. 183).

Esta interação dá-se em uma sistemática de linguagens verbais ou não verbais, estabelecidas pela completude do corpo, enquanto constituinte informativo. ${ }^{17} \mathrm{E}$ esta comunicação ocorre, na grande maioria das vezes, no nível inconsciente ${ }^{18}$, que para Meneghetti significa um "quântico de vida e de inteligência por meio do qual nós existimos, mas não conhecemos" (2012, p. 135).

Campo semântico seria, portanto, uma comunicação elementar, porque ocorre de forma a priori aos símbolos e às estruturas dos atos da percepção. Portanto, o encontro entre dois indivíduos permite que um intercepte semanticamente o outro por uma espécie de radarsemântico $^{19}$. Seria, noutras palavras, um deslocar intencional-psicoenergético de uma individuação a outra. Este outro, enquanto receptor, recebe esta pulsão emitida pela intencionalidade do emissor, consciente ou não, metabolizando-a.

Ainda, o termo semântico significa para o pensamento de Meneghetti um impulso que, enquanto se move, é capaz de gerar, a partir de uma informação, uma imagem, um determinado efeito no receptor, enquanto metabolizado (2010). O pensador italiano clarifica o significado, no seguinte sentido:

\begin{abstract}
Por "semântico" (de sema) se entende um especificar-se da realidade. O real chega codificado de modo inequívoco: uma carícia, um pontapé, uma indiferença, um medo etc. A realidade do indivíduo não chega de modo caótico, mas é sempre um exato formalizado sensível. A vida não conhece o desperdício, move-se segundo princípios de economia energética: tanto serve para comunicar, como emana de impelência ou impedância energética, sempre formalizada ao detalhe e traçada em
\end{abstract}

\footnotetext{
${ }^{16}$ Informação, para Meneghetti, significa, do latim: “in actio formo, signo = significa, assinalar a ação, dar estrutura à ação. Introduzir nova causalidade” (MENEGHETTI, 2015, p. 92).

${ }^{17}$ Inclusive em relação aos conceitos de cinésica e de proxêmica.

${ }^{18}$ Inconsciente: inconscius $=$ não sabedor, desconhecedor.

${ }^{19}$ Segundo Meneghetti (2015, p. 78) “o nosso corpo é um conjunto de radares e cada zona é específica em colher uma determinada informação do ambiente. Em todo o nosso organismo existem sensores que metabolizam o ambiente, seja externo que interno. A variação desses sensores depende da informação recebida; naturalmente, para colher estas variações é preciso ser totalmente consciente em si mesmo".
} 
modalidade organísmica. Portanto, "semântico" no sentido de significância, para denotar que a comunicação é um ato (MENEGHETTI, 2005, p. 37).

No entanto, para que seja possível esta comunicação no nível semântico, faz-se necessária uma espécie de sintonia entre o emissor e receptor. Em termos práticos, pode-se dizer, a exemplo, que em uma situação hipotética, o indivíduo comunicador emite um sinal semântico que, uma vez recebido pelo comunicado, pode ocasionar a este uma motivação, um desconforto, uma ação que, em sua origem, parte de uma informação transmitida pelo comunicador. Meneghetti explica que "no executor-colônia, a ação-impulso sofrida é percebida e executada como motivação própria ou egóica" $\left(1993\right.$, p. 9). ${ }^{20}$

Interessa-nos a partir de agora, explicitar o modo operacional do campo semântico. Meneghetti especifica o modus operandi da seguinte maneira:

Toda energia se baseia sobre um agente universal que é também vibração de espaço fluído. A sensação viscerotônica, ou a cerebrotônica de um campo semântico, constitui-se por alteração ou variação dos eletros dos corpos celulares de uma determinada zona (correspondente a uma exigência instintiva do emissor); a vibração causa deslocamentos sincrônicos e específicos no espaço fluído ambiente. A onda produzida no ambiente fluído, iguala-se aos elétrons dos corpos celulares de determinadas zonas do destinatário, correspondentes àqueles do emissor. O sistema de propriocepção do destinatário, recebe como sensação própria a informação do outro, desta adquire consciência própria e, na sua pseudoespontaneidade, se determina em resposta ao outro (1993, p. 11-12).

Esta informação recebida pelo comunicado, em uma relação ambiente, dá-se por imagens. ${ }^{21}$ Essa informação, emitida e recebida por imagem, atua no interior das individuações, no âmbito do inconsciente, sendo, em um primeiro momento, sempre neutra. $^{22}$

O modo de colher o campo semântico, para o pensador italiano, está relacionado ao recuperar uma exatidão da consciência e também ao manter-se em coerência em estilo de vida com o próprio em si. Trata-se de fazer o que denomina metanoia ${ }^{23}$, isto é, alinhar o seu agir lógico-histórico no mundo com o seu projeto de natureza.

\footnotetext{
${ }^{20}$ No que se refere à exatidão da ciência e do pesquisador, Meneghetti coloca a seguinte problemática: "não podemos considerar objetiva nenhuma pesquisa sobre o humano, se o pesquisador não tem experiência dos campos semânticos" (2015, p. 13).

${ }^{21}$ Imagem é um vetor de energia direcionado.

${ }^{22}$ Neutra porque a consequencialidade da própria imagem vai variar de como o sujeito interage e vetorializa a energia gerada a partir dela, podendo ou degradá-lo ou elevá-lo existencialmente.

23 Segundo o Dicionário de Ontopsicologia (2012a, p. 172), metanoia é a "reorganização em evolução progressiva de todos os modelos mentais e comportamentais".
} 
Cumpre destacar que para o referido pensador existem duas constantes no interior da psique do homem: uma pulsão proveniente do Em Si ôntico, que seria um instinto natural ao sucesso existencial, em conformidade ao ser, que aqui, para um olhar atento, obviamente parece assemelhar-se à vontade de potência ou instinto à superioridade ${ }^{24}$ (Der Wille zur Macht), no seu sentido positivo, de elevação ${ }^{25}$, e, por outro lado, uma informação que conduz o homem à violência, à degradação, denominado monitor ${ }^{26}$ de deflexão. ${ }^{27}$

Lançadas as pedras fundamentais do conceito e estrutura do campo semântico, cumpre-nos trazer no próximo capítulo os pontos de contato deste com a Einfühlung.

\subsection{O Campo Semântico na Fenomenologia de Einfühlung}

Do terreno ora explorado e, da natural dificuldade enfrentada, pode-se intuir uma proximidade entre o campo semântico e a Einfühlung, ou melhor, em verdade, intui-se que ambas consistem na mesma fenomenologia, isto é, de um mesmo mecanismo humano, ainda que se tenha algumas diferenças e especificidades, como se explicitará na sequência.

O método husserliano refere-se a uma reflexão dos fenômenos que se manifestam à consciência, como experiências, vivências; e estas são o objeto de análise da fenomenologia, na medida em que a consciência é sempre consciência de algo (1996, p. 7).

Em determinado ponto, Husserl questiona-se: "mas o que acontece então com os outros egos?" (1931/2001a, p. 105); e esta indagação reflete o resultado da descoberta da Einfühlung, ao indicar que "eles não são por certo simples representações e objetos representados em mim das unidades sintáticas de um processo de verificação que se

\footnotetext{
${ }^{24}$ Força motriz existente nos homens, animais, que instintivamente pulsaria em busca da superioridade, em busca de conquistas, realizações, isto é, ato em vetorialidade de expansão do ser. Essa vontade de poder, em cada individuação, pulsa e age por si só, orientada pela própria natureza. Nietzsche vai além de uma teoria darwinista, de que o homem busca apenas adaptar-se; acreditara, ao contrário, que o ser humano anseia a própria expansão no existir.

${ }^{25} \mathrm{Im}$ "Von der Selbst-überwindung": "Und wer ein schöpfer sein muss im Guten und Bösen: wahrlich, der muss ein Vernichter erst sein und Werte zerbrechen" (p. 88). Tradução do autor: "E quem quer que seja um criador no bem e no mal: verdadeiramente, deve primeiro ser um destruidor e quebrar valores". NIETZSCHE, F. W. Also Sprach Zarathustra. Berlim: Anaconda Verlag, 2005.

${ }^{26}$ Monitor de deflexão é uma espécie de mecanismo deformador da realidade antes da consciência. Em outras palavras, esse mecanismo antecipa-se à leitura das pulsões do Em Si direcionando o olhar do sujeito para uma visão sempre condicionado à sua estrutura, ao seu código. Por isso, "determina os modos de conhecimento do Eu" (MENEGHETTI, 2011b, p. 71).

${ }^{27}$ Em uma análise aos atos da consciência, isto é, os atos componentes do ser humano (Husserl), poder-se-á extrair que tanto o Em Si ôntico (ESO) quanto o monitor de deflexão representam atos da psique e não atos espirituais ou reflexivos. Significa dizer, noutras palavras, que são atos conscientes ou inconscientes, involuntários, não queridos. O ESO é captado, portanto, por intuição.
} 
desenvolve 'em mim', mas justamente nos 'outros'” (1931/2001a, p. 105). O filósofo alemão prossegue dizendo:

Percebo-os ao mesmo tempo como sujeitos desse mundo: sujeitos que percebem o mundo - esse mesmo mundo que eu percebo - e que têm, dessa forma, a experiência de mim, como tenho a experiência do mundo e nele, dos 'outros' (1931/2001a, p. 106).

E neste caminho é que Husserl desenvolve seu método, a redução fenomenológica ou epoché $^{28}$, que, em uma simplista explicação, serviria para encontrar, na singularidade do "eu”, uma essência daquilo que se mostra à consciência, um eidos; e esse eidos seria então justamente o aspecto universal daquele fenômeno, apreensível a todos.

Podemos considerar desde já como estabelecido o fato de que tenho em mim, no quadro de minha vida de consciência pura transcendentalmente reduzida, a experiência do "mundo" e dos "outros" (...) não como uma obra de minha atividade sintética de alguma forma privada, mas como um mundo estranho a mim, “intersubjetivo", existente para cada um (Husserl, 1931/2001a, p. 106).

Esta compreensão dá-se a partir da própria diferenciação das coisas, isto é, de suas essências, que as pessoas conseguem imediatamente perceber, como aquilo que tem ou não vida, ou a sua espécie, dentre outras características. Ainda neste sentido, depois de percorrido este caminho elucidativo, poder-se-á compreender os elementos basilares da Einfühlung. O primeiro, é o seu caráter imediato; e o segundo, é o conhecimento (pré-consciente) de que o alter tem uma estrutura vivencial igual à minha. Ales Bello:

Reconheço imediatamente: sei que ele tem todas as características estruturais que eu tenho, todas as possibilidades que eu tenho. Não sei, porém, quais possibilidades ele ativou verdadeiramente. Este é um segundo momento. Devo tentar entender, no sentido de sentir, quais possibilidades ele ativou, o que ele está vivendo (2004, p. 185).

Fica claro que esta breve investigação sirva para elucidar e, sobretudo, contribuir aos aspectos fenomenológicos do campo semântico e da Einfühlung. Como viu-se, Einfühlung é um ato natural do homem, é um ato não preparado e anterior aos atos perceptivos. É involuntário e pré-consciente (e por ser involuntário sugere-se constituir verdadeiro ato

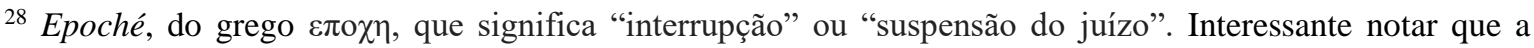
expressão epoché é utilizada pela primeira vez pelo céticos, no período helênico, como "suspensão do juízo" e, ao contrário do que muitos interpretam, a filosofia cética, principalmente de Pirro de Élis, não se dá pela negação da existência da verdade, mas sim, por uma suspensão do juízo e uma contínua investigação.
} 
psíquico, mesmo que em um nível diferente dos demais atos psíquicos), sendo diferente, portanto, dos atos espirituais, sob o ponto de vista estrutural do homem, estabelecido por Husserl.

Nesta perspectiva e sob a ótica dos atos da consciência, vê-se que o campo semântico, igualmente, poderia enquadrar-se como um ato psíquico, uma vez que é um ato instintivo e totalmente involuntário (pois não podemos escolher ter ou não este mecanismo), natural do homem, um sentir o alter, um verdadeiro instrumento natural do homem, que já nasce com ele. Aliás, do mesmo modo, não é preparado. Além disso, a influência husserliana no pensamento de Meneghetti é clara em suas obras. Interessante notar-se que o próprio pensador italiano referencia Edmund Husserl, por suas contribuições filosóficas, ao afirmar que:

É importante considerar que existiram grandes cientistas que, com amor, encontraram e conheceram Jung, Freud, Lewin, Binswanger e todos os outros que os fizeram estudar, e consideraram uma crítica pontual às suas teorias. Husserl é um filósofo que foi o grande professor de Martin Heidegger e ainda hoje não é facilmente compreendido. Porém, se alguém conhece a Ontopsicologia, Husserl é simplíssimo, porque ele sustenta que a análise científica estuda os fenômenos, os efeitos, não chega ainda à causa $(2019$, p. 42).

Definitivamente, ambos não são atos pré-preparados. Ainda assim, Davis (1990) supõe ser possível, fenomenologicamente falando, uma facilitação para o acontecimento da Einfühlung, ou seja, havendo o encontro entre indivíduos, necessariamente a vivência intersubjetiva irá acontecer e, neste acontecer, a tomada de consciência destes atos poderia ser (mais facilmente) intuída. É exatamente o mesmo que dizer que o estudo do campo semântico permite uma facilitação da compreensão das estruturas fundamentais na vivência humana.

Em ambos os casos, comunicante e comunicado, simultaneamente, sofrem alterações biopsíquicas pela troca contínua de informações a nível semântico, isto é, um está necessariamente alimentando o outro, agindo negativamente ou positivamente sobre o outro.

Esta similaridade inclusive pode ser notada na percepção dos estudos desenvolvidos por Edith Stein, principal discípula de Husserl, e outros autores. A exemplo, em sua obra, Safra, fazendo uma análise sobre as proposições fenomenológicas aqui postas em relevo, manifesta que "o analista intuiu o que se passa (...) pelo fato de seu corpo estar sendo continuamente afetado pela forma de ser do paciente" (2006, p. 48). 
A Einfühlung significa, portanto, exata e primeiramente, uma completa perceptividade de que estamos diante de um outro, seja ser humano, seja outro animal, seja outro ser vivo, seja outro objeto. A primeira dimensão não poderia ser outra que não a de reconhecer um alter ego, vivente ou não.

O segundo momento dá-se justamente pela analítica perceptiva do alter, se se tem ou não uma mesma estruturação vivencial desenvolvida ${ }^{29}$. Edith Stein aprofunda ainda o tema da Einfühlung (que, conforme já mencionado, para alguns autores e em algumas traduções para o português, é referido como sinônimo de "empatia", em sua forma traduzida da palavra original), como sendo uma vivência passível de compreensão consequencial dos atos vividos pelo outro, mas, de todo modo, de impossível vivência-idêntica. Nas suas palavras, Edith Stein diz que "a percepção externa é um título de atos no qual o ser coisal espaço-temporal e o seu realizar se dão em carne e osso" (1917/1918, p. 72).

Desta proposição pode-se imediatamente questionar: "se não se pode compreender identicamente o vivenciado pelo outro, como posso saber se aquilo que percebo a nível semântico é, ou não, real?". Esta, sem dúvidas, é uma das maiores dificuldades no terreno arenoso percorrido nesta investigação. Aliás, este enunciado parte da premissa posta em análise a partir do próprio estudo fenomenológico sobre a Einfühlung, como, a exemplo, na compreensão de Bello, para querm "o dado entropatizado não pode ser idêntico ao dado entropatizante" (Ales Bello, 2005, p. 50, tradução própria). Não se pode viver o vivido do alter de modo idêntico.

Neste nível, pode-se intuir não uma similaridade, mas sim uma identidade. Einfühlung significa em suas análises mais profundas, especialmente desenvolvidas por Edith Stein, o mesmo que campo semântico. O que inegavelmente muda é a formalização científica tratada por Meneghetti, que, em sua contemporaneidade, representa um avanço à investigação e também à sua explicitação.

Esta experiência da Einfühlung/semântica depende de um "eu puro", ou melhor, de uma subjetividade pura. Tanto Husserl quanto Meneghetti apresentam esta via como o caminho a ser percorrido para uma correção da consciência ao mundo-da-vida. Meneghetti admite que "a epoché ainda não esclareceu nada, é apenas o portão de entrada" (2009, p. 276). Por outro lado, Stein explica que não se trata de um idealismo platônico posto em

\footnotetext{
${ }^{29}$ Isso significa que ainda que as pessoas tenham uma mesma estrutura, isto é, percepção corpórea, psíquica e espiritual, não as desenvolvem de modo igual, possuindo, assim, mais ou menos capacidade de percepção sensorial, psíquica e reflexiva, enquanto ato espiritual, por exemplo.
} 
relevo como verdade absoluta, "não é uma ideação, dado que se trata de colher isto que existe 'hic et nunc' [aqui e agora]” (1998, p. 73). E continua:

\begin{abstract}
Na minha experiência vivida não originária, eu me sinto acompanhado de uma experiência vivida originária, a qual não foi vivida por mim, apenas se anuncia em mim, manifestando-se na minha experiência vivida não originária. De tal modo, nós chegamos por meio da empatia a uma espécie de ato experiencial sui generis (1998, p. 75).
\end{abstract}

E esta aproximação entre os conceitos de Einfühlung e campo semântico, embora, aparentemente, seja pioneira, não significa que já não tenha sido intuído por outros autores. E é neste sentido que, em última instância, Carotenuto afirma que a compreensão do campo semântico, enquanto descoberta, já havia sido intuída por outros pensadores:

É fácil compreender que o Em Si ôntico, o campo semântico e o monitor de deflexão são três conhecimentos imprescindíveis para realizar a exatidão da consciência humana. O conhecimento absolutamente novo é aquele do Em Si ôntico, as outras duas já haviam sido intuídas, mas sempre descritas com linguagem ou religiosa, ou mágica, ou esotérica, de todo modo sem a exatidão científica que lhe consentisse a identificação e a possibilidade de experimentação racional (2009, p. 257).

Deste ponto, pode-se extrair duas conclusões: a primeira é que de fato o campo semântico representa uma evolução científica acerca da Einfühlung, isto é, significa que se pôde compreender de modo mais racional, em termos metodológicos, e também de forma mais simplificada; ${ }^{30}$ e, por outro lado, incorreto conjecturar que a intuição do campo semântico estaria, na história da humanidade, apenas ligada a intuições religiosas, mágicas ou exotéricas. Existe, sim, uma dificuldade científica na interpretação do assunto, mas, de todo modo, já fora suficientemente abordado de modo científico por Husserl e Edith Stein e, posteriormente, por Meneghetti.

Por fim, inclusive, a descoberta dos neurônios espelho por Rizzolatti, na década de 90, assemelha-se, numa concepção biológica e neurológica, à ação fenomenológica do campo semântico/Einfühlung. Os neurônios espelho são, para Riozzolatti (Gallese, 2005), reações que, quando ativados pela observação de uma determinada ação, permitem que esta fenomenologia seja automaticamente compreendida, de modo pré-atencional, isto é, antes das etapas conscientes, através de mecanismos cerebrais sofisticados.

\footnotetext{
${ }^{30} \mathrm{O}$ que não significa dizer, todavia, que o campo semântico partiu do conceito de Einfühlung.
} 
Portanto, a investigação posta em relevo demonstra, de forma segura e concreta, a similaridade da Einfühlung e do campo semântico, constituindo-se, ambos, por serem um mecanismo natural capaz de compreensão pré-atencional/consciente sobre os atos vivenciais, ainda que ambos os conceitos sejam apresentados, cientificamente, em níveis diferentes de elaboração.

\section{Considerações Finais}

A presente investigação demonstrou não só a complexidade do tema abordado, mas, especialmente, a relação entre as teorias da Einfühlung e do campo semântico. Naturalmente, o estudo, além de revelar de forma pioneira esta aproximação, também evidenciou as suas dificuldades e, sobretudo, que há ainda um caminho muito extenso a ser percorrido ainda sobre a temática posta em análise.

Com efeito, para chegar à resposta da problemática teorizada, utilizou-se o método de pesquisa dialético, confrontando-se, deste modo, a teoria husserliana àquela proposta por Meneghetti. E este percurso deu-se pelo objetivo central de verificar a relação existente, ou não, entre a teoria husserliana da Einfühlung, com a do campo semântico, proposta pelo pensador italiano.

E, neste sentido, com o primeiro tópico pôde-se concluir que a Einfühlung, de modo geral, é uma apreensão por semelhança imediata. Permite-se, com isso, um acesso anterior imediato e involuntário à interioridade do fenômeno alter ego, captando sua identificação instantânea e sua distinção, e, em um segundo momento, concomitantemente aos demais atos perceptivos, pode-se chegar à compreensão consciente das informações captadas pela Einfühlung.

O conceito de campo semântico, por sua vez, caracteriza-se por ser uma comunicação base-elementar, que ocorre de forma a priori aos símbolos e às estruturas dos atos da percepção. É, desta forma, um mecanismo de transdução informática que, em si, não transfere energia.

Portanto, a partir do percurso investigativo posto em relevo, pode-se concluir que os conceitos teoréticos da Einfühlung e do campo semântico constituem-se de forma similar, caracterizando-se, ambos, por serem um mecanismo natural e inteligente, que é capaz de compreensão imediata pré-atencional/consciente sobre os atos vivenciais. 


\section{Referências}

ARISTÓTELES. De Anima. 34. ed. Apresentação, tradução e notas de Maria Cecília Gomes Reis. São Paulo, 2006.

BELLO, A. A. Introdução à Fenomenologia. Tradução: Ir. Jacinta T. Garcia e Miguel Mahfoud. Bauru/SP: Edusc, 2006.

BELLO, A. A. (1998). Prefazione alla seconda edizione. Em E. Stein. Il problema dell'empatia. (E. Costantini \& E. Schulze-Costantini, Trads.). Roma: Studium. (Original publicado em 1917).

BELLO, A. A. (2004). Fenomenologia e ciências humanas: psicologia, história e religião (M.nMahfoud \& M. Massimi, Orgs. e Trads.). Bauru, SP: EDUSC. (Original publicado em 2004).

CARNEIRO, C. Lateralidade, percepção e cognição. Cérebro e mente. 13. ed. Campinas: UNICAMP, 2001.

CAROTENUTO, M. Histórico sobre as teorias do conhecimento. Tradução Ontopsicológica Editrice. São João do Polesine: Ontopsicológica Editrice, 2009.

GALLESE, V. What do mirror neurons mean? Intentional Attunement. The Mirror Neuron system and its role in interpersonal relations, 2005.

GUIMARÃES, A. C. Fenomenologia e direitos humanos. Rio de Janeiro: Lúmen Juris, 2007.

HUSSERL, E. A ideia da fenomenologia. Lisboa: Edições 70, 1989.

HUSSERL, E. Investigações Lógicas: sexta investigação. São Paulo: Editora Nova Cultura, 1996. (Coleção Os Pensadores).

HUSSERL, E. (2001a). Meditações cartesianas: introdução à fenomenologia. (F. Oliveira, Trad.). São Paulo: Madras. (Original publicado em 1931).

HUSSERL, E. Ideias para uma fenomenologia pura e para uma filosofia fenomenológica: introdução geral a fenomenologia pura. Trad. Márcio Suzuki. Aparecida: Ideias \& Letras, 2006.

SANTOS, J. M. Os Argonautas da Razão. Da Fenomenologia à Teoria dos Sistemas. Phainomenon, [S.1.], n. 14, p. 45-60, oct. 2007. ISSN 2183-0142.

MANGANARO, P. Verso l'altro: l'esperienza mistica tra interiorità e trascendenza. Roma: Città Nuova, 2002.

MENEGHETTI, Antonio. Campo Semântico. Porto Alegre: ABO, 1993. 
MENEGHETTI, Antonio. Cinco Lições de Ontopsicologia. Recanto Maestro: Ontopsicológica Editrice, 2005

MENEGHETTI, Antonio. Manual de Ontopsicologia. Recanto Maestro: Ontopsicológica Editora Universitária, 2010.

MENEGHETTI, Antonio. Conhecimento ontológico e consciência. Recanto Maestro: Ontopsicológica Editora Universitária, 2011.

MENEGHETTI, Antonio. Dicionário de Ontopsicologia. 2. ed. Recanto Maestro: Ontopsicológica, 2012a.

MENEGHETTI, Antonio. Imagem e Inconsciente. 4. ed. Recanto Maestro: Ontopsicológica Editora Universitária, 2012b.

MENEGHETTI, Antonio. Da consciência ao ser: como impostar a filosofia do futuro. Recanto Maestro: Ontopsicológica Editora Universitária, 2014.

MENEGHETTI, Antonio. Campo Semântico. 4. ed. Recanto Maestro: Ontopsicológica Editora Universitária, 2015.

NIETZSCHE, F. W. Also Sprach Zarathustra. Berlim: Anaconda Verlag, 2005.

SAFRA, G. Hermenêutica na situação clínica: o desvelar da singularidade pelo idioma pessoal. São Paulo: Sobornost, 2006.

STEIN, E. II problema dell'empatia. 2. ed. Trad. Costantini e E. Schulze-Costantini. Roma: Studium, 1988.

VIDOR, A. Fenomenologia e Ontopsicologia: de Husserl a Meneghetti. Recanto Maestro: Ontopsicológica Editora Universitária, 2013. 